\title{
SOBRE OS PROFISSIONAIS DA AVENTURA ${ }^{1}$ : PROBLEMAS DA ATUAÇÃO NA INTERFACE ESPORTE E TURISMO ${ }^{2}$
}

Recebido em: 03/02/2015

Aceito em: 10/07/2015

\author{
Marília Martins Bandeira ${ }^{3}$ \\ Olivia Cristina Ferreira Ribeiro ${ }^{4}$ \\ Universidade Estadual de Campinas (Unicamp) \\ Campinas - SP - Brasil
}

RESUMO: O objetivo deste trabalho foi descrever e analisar criticamente, a partir do município de Brotas, São Paulo, autointitulado capital brasileira da aventura, as condições de trabalho dos, autodenominados, profissionais da aventura. Como metodologia, este artigo apresenta o cruzamento de dados de duas pesquisas: uma etnografia sobre as rotinas da aventura e uma triangulação de análise documental, observação participante e entrevistas com gestores desse município. Encontramos que apesar de haver uma disputa política entre entidades do turismo e do esporte, a realidade de seus profissionais borra as fronteiras desses campos. Concluímos que pensar a aventura como campo híbrido em uma acepção mais geral de lazer pode auxiliar em posturas mais colaborativas para a resolução dos problemas da formação e da atuação profissionais, tais como: informalidade, sazonalidade, baixa remuneração e periculosidade.

PALAVRAS CHAVE: Atividades de Lazer. Esportes. Trabalho.

\section{ABOUT THE AVENTURE PROFESSIONALS: PROBLEMS IN THE ACTUATION IN SPORTS AND TOURISM}

ABSTRACT: The objective of this study was to describe and analyze critically, from the municipality of Brotas, São Paulo, Brazil's self-titled adventure capital, the working conditions of, self-appointed, adventure professionals. As methodology, this article presents the intersection of data from two researches: an ethnography on the routines of adventure and a triangulation of documentary analysis, participant observation and interviews with managers of this municipality. We found that although there is a political dispute between tourism and sports entities, the reality of their professionals blurs the boundaries of these fields. We conclude that thinking adventure as a hybrid field, in a more general sense of leisure, can assist in more collaborative attitudes towards solving the problems of training and professional practice, such as informality, seasonality, low pay and dangerousness.

\footnotetext{
${ }^{1}$ Como preconiza a escrita antropológica, os termos específicos do campo serão apresentados em itálico.

2 Este artigo contém dados de pesquisa de mestrado financiada pela Capes, cruzados com dados de pesquisa de doutorado financiada pela Fapesp.

${ }^{3}$ Doutoranda na Faculdade de Educação Física da Universidade Estadual de Campinas

${ }^{4}$ Docente dos cursos de licenciatura e bacharelado em Educação Física da FEF/Unicamp
} 
KEYWORDS: Leisure Activities. Work. Sports.

\section{Introdução: Aventura $^{5}$ Como Lazer}

O objetivo do presente artigo é descrever e analisar criticamente as condições de trabalho em um campo de lazer relativamente recente no Brasil: as práticas de aventura, a partir da cidade de Brotas, no interior do estado de São Paulo, autointitulada capital brasileira da aventura. Tal objetivo surgiu a posteriori em relação aos projetos de pesquisa que o originaram, pois, no momento das pesquisas de campo que compõem este trabalho, uma interessada nas políticas públicas de lazer e a outra nos significados da noção de aventura, identificaram-se em curso três conflitos políticos: as políticas públicas de lazer em Brotas privilegiavam os visitantes e não a população local, os empregados da aventura reivindicavam melhores condições de trabalho a seus empregadores e, em âmbito nacional, entidades do turismo e do esporte disputavam judicialmente o direito de regulamentar a exploração comercial das práticas de aventura.

Entretanto, apesar da possível dissociação institucional em esporte e turismo, os dados desta investigação apontam para uma complexa variabilidade de atuações que borram as fronteiras de uma ou outra área, tornando difícil uma classificação precisa. Pessoas formadas no esporte competitivo que empreenderam ou se empregaram oferecendo sua modalidade atlética como experiência pontual ou passeio a leigos e que entendem isso como turismo; pessoas que encontraram no trabalho com turismo o acesso a equipamentos necessários para se tornarem atletas de alto rendimento; pessoas que vivem um turismo esportivo ou um esporte turístico, ao conceberem esporte não necessariamente como atividade competitiva ou regrada, mas no sentido do desafio

\footnotetext{
5 A opção pelo termo aventura se dá por ser, em terminologia antropológica, "termo nativo", ou seja, o termo operado por aqueles que o vivem.
} 
físico e da dimensão lúdica da expedição autônoma; membros das classes mais desprovidas que afirmam ter buscado como trabalho práticas que desejavam como lazer, mas que não podiam custear; e, ainda, nativos que foram procurados por visitantes em busca de seus saberes sobre o meio ambiente local, e que passaram a atuar como guias, sem qualquer formação institucional, demonstram que o campo é híbrido. O que não é novidade, já que os estudos inaugurais de Costa (2000), intitulado Esportes de Aventura e Risco na Montanha, foi realizado na Educação Física, mas se utilizava de material de publicidade do turismo de aventura para construir seus dados e Uvinha (2001) passa do conceito de esportes radicais a atuar com o de turismo de aventura (2005), o que sugere que esta troca e dinamismo não são questões recentes.

Não utilizamos o termo esportes radicais pois ele foi eliminado pelos pesquisados no processo de nomear seu campo, por julgarem que tal expressão remetia a risco exacerbado e conhecimento técnico prévio, o que inibiria certos perfis de clientes. Inspiradas por Schwartz $(2004,2006)$ e seu grupo de pesquisa, quando da criação do Congresso Brasileiro de Atividades de Aventura, para oferecer alguma possibilidade de compreensão mútua e mediação destes conflitos, propomo-nos, não a tomar uma decisão arbitrária e a priori pelo recorte do que poderia ser apenas turístico ou esportivo no campo da aventura, mas a pensar a aventura como lazer em seu sentido mais abrangente.

Entretanto, não adotaremos, como a autora, a expressão e sigla Atividades Físicas de Aventura na Natureza (AFAN) de Betrán (2003), pois apesar de buscar precisão conceitual ela se torna longa e estranha aos próprios praticantes. Já a expressão esportes na natureza, sugerido por Dias, Mello e Alves Jr (2007), foi encontrada em campo, mas em menor frequência e neste contexto específico, em que o risco é central, ela pode ser muito abrangente por não sinalizar a aventura, e ao mesmo tempo excludente, pois não 
prevê o componente turístico. Ao invés de esporte, então, preferimos pensar a aventura como lazer.

A literatura em estudos do lazer no Brasil preconiza que o mercado de trabalho em lazer é muito diversificado: clubes, buffets, shoppings, restaurantes, hotéis e acampamentos, sistema "S", empresas de eventos e recreação, as diversas mídias de entretenimento, navios de cruzeiros e, acrescente-se aqui, agências ou operadoras turísticas, entre outras. E que são inúmeras as funções que um profissional do lazer pode assumir: planejamento, organização, execução e avaliação; gerenciamento, coordenação, supervisão e avaliação de projetos, viabilização de projetos e recursos, realização, registro e socialização de pesquisas, entre outros (WERNECK et al., 2001; ISAYAMA, 2006). O que corresponde também às funções necessárias à viabilização da aventura enquanto serviço.

Isso também significa que profissionais de diferentes formações são necessários para atuar nesta área, como aqueles formados em Educação Física, Turismo, Hotelaria, Pedagogia, Administração, Sociologia, Arquitetura, entre outros (WERNECK et al., 2001; MARCELLINO et al., 2007). Entretanto, as agências de turismo ou operadoras de aventura de Brotas não exigem formação acadêmica para a atuação em aventura, o que também é confirmado por outros autores e acontece em outros contextos (SCHWARTZ \& CARNICELLI FILHO, 2006; CORREA, 2008; FIGUEIREDO, 2011; PAIXÃO et al, 2011; ARAÚJO, 2012; AURICCHIO, 2013).

Marcellino (2006), Werneck et al. (2001) e Isayama (2006) sugerem que é necessário o profissional do lazer ter formação e conhecer com profundidade os conteúdos culturais com os quais vai atuar e, ao mesmo tempo, ter visão de conjunto de todos os outros que o perpassam. "É necessário lembrar que algumas podem ser 
desenvolvidas apenas por professores de educação física, outras por arte-educadores, outras por profissionais de turismo, etc" (MARCELLINO, 2006, p. 11).

Baseado em Dumazedier (1980) ${ }^{6}$ e Camargo (1992), que incluiu as atividades turísticas como um interesse de lazer na lista do primeiro, Marcellino (2006) parece, neste trecho, não contestar as tradições disciplinares e sindicais. Entretanto, as categorias cunhadas para agrupar conjuntos práticas, se, por um lado, foram necessárias na época em que teorias totalizantes eram fundamentais para justificar a importância dos estudos do lazer e ajudaram a organizar conteúdos e propostas de intervenção, por outro, nunca atendeu as práticas de difícil classificação, mistas, ou deliberadamente subversivas. O mesmo ocorre com a abordagem "politicamente correta" sobre as profissões universitárias.

Nesse sentido, acreditamos mais profícuo para a solução dos problemas práticos discutir o caso peculiar da aventura em profundidade, a partir de um recorte empírico, do que pretender adicionar categorias generalizantes (como atividades na natureza, lazer de risco ou práticas de aventura) a uma "teoria geral do lazer" e expandir tais listas que se tornam inevitavelmente e rapidamente obsoletas já que a vida social é dinâmica e criativa. No campo desta pesquisa, foi verificado um borrar de fronteiras entre conteúdos físico-esportivos, turísticos e ambientalistas. Além disto, nenhuma formação acadêmica universitária era exigida para a atuação nos serviços de aventura, embora no campo da presente pesquisa, se tenha notado alguns egressos e ingressantes de cursos universitários, principalmente de Turismo e de Educação Física.

Figueiredo (2011), ao investigar 39 empresas de 12 estados do Brasil, com a limitação de que a autora buscou aquelas que se identificam como turismo de aventura,

\footnotetext{
${ }^{6}$ Dumazedier classificou os interesses culturais do lazer em: fisico-esportivos (os esportes e atividades físicas em geral), artísticos (cinema, teatro, espetáculos de dança, música, artes plásticas, literatura, pintura etc.); manuais (tricô, crochê, bordado, confecção de bijuterias etc.); intelectuais (dama, xadrez, participação em palestras e cursos) e sociais (festas, churrascos etc.)
} 
constata que o empregador vê a experiência prática na modalidade de atuação como mais importante do que qualquer curso superior e $71 \%$ delas afirmam oferecer capacitação específica a seus funcionários, principalmente cursos de primeiros socorros e procedimentos técnicos. Araújo (2012), em Belo Horizonte, e Auricchio (2013), em Boituva, Socorro e Guarujá, encontram dados semelhantes entre os profissionais da aventura, que também acreditam que experiência prévia na modalidade de atuação é mais importante que uma formação institucional. Paixão; Costa e Gabriel (2009) concorda com tais dados mas, ao conceber a aventura exclusivamente como esporte, afirma que a formação é falha, pois se dá em cursos de mínima duração oferecidos por confederações esportivas ou associações internacionais certificadoras relativas a modalidades especificas e que não garantem a capacitação para a administração de atividade física, em que pese as condições de saúde e condicionamento dos diferentes clientes. Para o autor, a inexistência de um perfil de atuação e de uma institucionalidade formal faz desta atuação não uma profissão, mas uma ocupação. Na presente pesquisa, defendemos que esta forma de conceber a atuação em aventura, embora a necessidade da crítica, é desrespeitosa com os saberes não institucionais e complexos demandados na aventura.

Desde o caso brotense, pudemos compreender que, em contextos nos quais o rafting $^{7}$ é o carro-chefe do lazer de aventura, assim como as trilhas ${ }^{8}$ e o canionismo ${ }^{9}$, a familiaridade com o rio ou a mata, um certo saber local, para parafrasear Geertz (1983), e a facilidade em navegação e orientação, mesmo que não sistematizadas, são por vezes suficientes para que o futuro profissional inicie do zero a aquisição técnica de modalidades específicas. Na prática, mais vale quem conheça o ambiente da atividade

\footnotetext{
${ }^{7}$ Navegação em rio de corredeira com bote coletivo inflável e remo de uma pá.

${ }^{8}$ Caminhada em meio à natureza.

${ }^{9}$ Fruição de cânions por meio de combinações de técnicas de flutuação e verticais, ou seja, manejo de cordas, freios, cinto-cadeirinha de segurança e mosquetões para a transposição de diferentes alturas (principalmente as técnicas de descida, como rapel e tirolesa).
} 
ou a técnica da modalidade e consiga sobreviver e transitar em fenômenos naturais diversos, do que quem tem um título e contato sistemático com o conhecimento institucional e teórico, mas não saiba operacionalizá-lo.

Não se trata aqui de dispensar a necessidade de formação no ensino superior, ou de diálogo da aventura com o meio acadêmico, o que é sempre bem-vindo e complementar, mas de lembrar que os saberes nativos, locais, populares, tradicionais e/ou não institucionalizados não são modos inferiores de saber, mas, sim, modos diferentes e que também precisam ser valorizados, já que as trocas entre pessoas distintas e diversos níveis de educação formal, nesses contextos, foram não apenas possíveis, mas necessárias. A aventura é, portanto, transdisciplinar (CORREA, 2008), no sentido de que está além da multi e da interdisciplinaridade, por incluir aquilo que não é disciplinar.

Além disto, as diversas denominações recebidas pelo profissional do lazer: animador, recreador, recreacionista, animador cultural, gentil organizador, entre outros, dependendo da organização em que atua, além do cargo e/ou função que ocupa, caracterizadas por Stoppa et al (2010), ainda não ajudam a pensar o contexto da aventura. A terminologia no campo deste estudo é própria, mas também não é consenso e é objeto de disputa não só simbólica como também política.

Em Brotas, encontramos os termos instrutor, monitor, guia ou condutor no que se refere à atuação profissional em aventura. Os dois primeiros têm sido combatidos pelas agências turísticas, diante da reivindicação das entidades esportivas e do Conselho Nacional de Educação Física (Confef) de que os profissionais devem ter curso superior específico e/ou vinculação a confederações, ou a associações esportivas para serem aptos a ensinar ou a supervisionar seus clientes tecnicamente. Os dois últimos são frequentes e muitas vezes intercambiáveis se tratados da perspectiva do turismo, pois 
conferem aos ofícios da aventura a conotação de passeio proporcionado tecnicamente pela expertise profissional, embora o termo guia tenha uma definição anterior ao cenário comercial da aventura na Embratur (antiga Empresa, atual Instituto Brasileiro de Turismo). Por isso, a nomenclatura guia foi entendida como inadequada e evitada (por priorizar o saber histórico sobre o destino, enquanto, no caso da aventura, é a disposição física e a concordância em viver o risco proporcionado pelos imponderáveis da natureza que caracteriza a atuação). O termo condutor foi, então, cunhado pelos agentes do turismo na prática e na reflexão específica dos serviços de aventura $^{10}$.

Embora agentes do esporte acusem os agentes do turismo de terem criado nova nomenclatura para escaparem da legislação e da regulamentação já existentes, o último termo será utilizado neste artigo, por ser um dos mais proferidos pelos estudados ao denominarem sua atuação profissional em Brotas e aquele considerado o mais adequado oficialmente. Como "oficialmente" quer dizer que foi implementado pelos empreendedores e empregadores influentes no Ministério do Turismo, além dele, utilizaremos o termo profissionais de aventura, termo mais acionado pelos empregados com a intenção de conferir ao seu ofício conotação de profissionalismo, seriedade e formalidade, a partir da qual desejavam ser tratados e também porque não permite diferir áreas de atuação. Procedamos, após a apresentação da metodologia, à demonstração destas abstrações com os dados de campo.

\section{Metodologia}

Este artigo apresenta o cruzamento de dados de duas pesquisas distintas, uma dissertação de mestrado em Antropologia Social e uma tese de doutorado em Educação

\footnotetext{
${ }^{10}$ É importante salientar que esta tendência varia conforme a modalidade principal de cada campo de pesquisa. Por exemplo, o montanhismo e a escalada operam o termo guia com outra conotação (DIAS; ALVES JUNIOR, 2007). No voo livre, há a especificidade do termo piloto (PIMENTEL, 2006), enquanto este trabalho trata de contexto no qual o rafting é a modalidade principal.
} 
Física, realizadas em período próximo, no mesmo campo de estudos: a auto-intitulada capital brasileira da aventura, a cidade de Brotas, no interior do estado de São Paulo.

A metodologia do primeiro estudo é etnográfica e de orientação antropológica. E concebe a Antropologia como uma ciência que busca, em realidades objetivas, temas contestadores das teorias científicas e do senso comum estabelecidos (é uma contraprodução deliberada, segundo STRATHERN, 2006), privilegia o diferente e o ponto de vista do pesquisado (GEERTZ, 2012), sem esquecer que ele é percebido na relação com o ponto de vista de um pesquisador, que é, por sua vez, distinto de outros (CLIFFORD, 2008). Assim como a abordamos, valoriza-se a alteridade por acreditar que ela cumpra, no âmbito das ciências e direitos humanos, melhor papel diplomático e mediador que qualquer generalização sobre o humano, porque cria bases para a compreensão de peculiaridades em conflito.

A etnografia, assim como a concebemos, prevê a maior imersão possível no campo de pesquisa e o cruzamento de tantos procedimentos metodológicos quanto autorizados pela realidade social estudada, zelando por continuidade, em termos de tempo de duração e vínculo social com os pesquisados, para que permita o registro não só das rotinas e permanências, como também de transformações técnicas e mudanças políticas. Neste caso, o trabalho de campo durou aproximadamente nove meses (Junho de 2010 a Março de 2011) de imersão total e observação participante (ou seja, morar na cidade, trabalhar e treinar com os pesquisados).

Partindo desses pressupostos, no caderno de campo, foram narradas a observação direta e a observação participante (WACQUANT, 2002), que foram confrontadas na análise dos dados com a pesquisa documental (publicações oficiais, material de propaganda das agências de turismo de aventura, apostilas de treinamento de condutores, fichas de registro de atividades e websites) e trinta e cinco entrevistas 
abertas com condutores de aventura que atuaram em quatro diferentes empresas de Brotas (gravadas em áudio e cujas citações são identificadas por letras aleatórias para conferir anonimato aos voluntários).

A segunda pesquisa tratou de um estudo de caso das políticas públicas de lazer (MINAYO; DESLANDES; GOMES, 2009) da mesma cidade. Para tanto, a triangulação de dados foi utilizada, por meio da pesquisa documental, da observação participante e de entrevistas. $\mathrm{Na}$ primeira, foram analisadas legislações diversas de Brotas, no que se refere ao lazer, das Secretarias de Esporte, Cultura e Recreação, Turismo, Ação Social, Meio Ambiente e Saúde, Câmara de Vereadores, programas, decretos e atas. A observação participante complementou a análise documental com o uso de diário de campo nas reuniões das Secretarias de Turismo, Diretoria de Esportes e Conselho Municipal de Turismo (acompanhadas mensalmente entre os meses de dezembro de 2011 e outubro de 2012). Nessa pesquisa, 16 entrevistas semiestruturadas foram realizadas com gestores e a maioria dos servidores das Secretarias citadas (com exceção dos da de Saúde, que não aceitaram participar das entrevistas). Um termo de consentimento livre e esclarecido foi assinado pelos entrevistados, como previsto na normativa do Comitê de Ética ao qual o trabalho foi submetido, cujo parecer é o de número 07869812500005404.

\section{Resultados E Discussão}

\section{A Invenção Do Profissional De Aventura}

O município de Brotas tem como suas principais atividades econômicas a agroindústria canavieira, a cultura da laranja, a silvicultura, a pecuária e o turismo (BROTAS, 2012). Esta conformação socioeconômica se deu depois de uma crise no programa PróAlcool. Com a economia em baixa no final da década de 1980, a cidade 
foi abordada por um curtume, mas ambientalistas locais, embalados pelo período pósECO-92 fundaram a organização não governamental Movimento Rio Vivo, para impedir sua instalação e propor o ecoturismo como alternativa. Esse movimento levou à criação da Secretaria Municipal do Meio Ambiente, em 1993, e da primeira agência turística a oferecer trilhas e banhos de cachoeira guiados na cidade: a Mata D'entro.

Com a concorrência de outros destinos de ecoturismo, principalmente Bonito (MS) e com outras agências se formando, percebeu-se que o diferencial geográfico de Brotas permitia, além do ecoturismo de contemplação, oferecer passeios ativos, temperados com o risco proporcionado pelos rios de corredeira e cânions da localidade. Atuar nessas práticas, principalmente no rafting, foi a oportunidade que muitos brotenses, acostumados a descer o rio de boia, encontraram para obter um emprego e na cidade, em um período de estagnação econômica. Este quadro contextualiza a fala de um dos nossos entrevistados:

No meio do interior sertanejo, o pessoal gosta de mandar uma cachaçada para baixo, cerveja, e vai fazer o quê? Não tem opção. Se você não gosta da escola, ou você vai cortar cana, colher laranja, ou vai ser pedreiro. Se não estudar, não tem outra opção. É trabalho braçal mesmo. E quando vê, caiu na cachaça. E aí a aventura chegou na cidade estruturada como uma opção de trabalho, uma opção mesmo de ganhar dinheiro com uma coisa que a gente gostava... Eu gostava de fazer o quê, na cidade, quando mais novo? Nadar no rio, curtir a noitada, conhecer pessoas. E o turismo é isso, né? Só que você tem que ganhar responsabilidade por operar estas atividades. Você ganha conhecimento, vai buscando técnica, vai ficando mais responsável e cada vez mais fora de riscos, vamos dizer. Faz os cursos, conhece os equipamentos, os seguros. Mas é claro que a minha primeira motivação para buscar isso foi a adrenalina da coisa, né? Porque é gostoso. Então, quando eu cheguei pra aventura eu queria curtir, mas mudou, isso virou ganho de conhecimento, porque tudo que eu não sabia, eu comecei a ganhar dentro do esporte que eu escolhi fazer. Viajar... muito. Viajei o país inteiro, tive chance de conhecer do sul até o nordeste. Vários pontos que o pessoal paga fortuna para ir e eu nunca ia conseguir, eu fui ganhando alguma coisinha, trabalhando, dando curso de salvamento, porque eu fui buscar conhecimento de tudo isso. 
Aventura, portanto, é oportunidade de emprego em meio à crise nesta localidade e ganha a face de trabalho prazeroso e em acordo com a identidade local de relação íntima com o rio Jacaré Pepira e valores contemporâneos como a sustentabilidade ${ }^{11}$, o entretenimento e a valorização das viagens. Em meados de 1990, os poucos praticantes autônomos de rafting e canionismo que passaram a "levar os leigos junto" e oferecer suas técnicas como serviço, não foram capazes de absorver a alta demanda. Criaram agências que passaram a recrutar nativos, para os quais ofereceram treinamento técnico específico, enquanto a Prefeitura elaborava uma política para a transformação de Brotas em destino turístico.

Nesta cidade, portanto, a atuação em aventura foi entendida como adequada a gostos, limitações e habilidades que corresponderiam à disposição prática do operário, ou trabalhador braçal brotense: o caipira, sertanejo ou mateiro pouco escolarizado, mas que detém um saber local demandado: aquele sobre o ambiente no qual a aventura acontece. Esse dado corrobora o que diz Auricchio (2013, p. 24), para quem "tais empresas são geridas por pessoas com experiência em determinadas atividades que contratam mão de obra local, muitas vezes com pouca ou nenhuma experiência" na modalidade técnica específica.

Para os provenientes das camadas socioeconômicas mais privilegiadas, a condução foi procurada como atividade temporária, como um ofício-brincadeira eventual, ou um trabalho da juventude. Já para a mão de obra jovem proveniente das classes menos privilegiadas, excedente e desesperançada, a procura pelo mercado da aventura brotense acontece, não só por ser um mercado crescente, mas por gozar de um status diferenciado daquele do colhedor de laranja, do cortador de cana e do pedreiro.

\footnotetext{
${ }^{11}$ Segundo Rodrigues (2012), tudo o que sugere relação com a causa/preservação/educação ambiental passa a ser positivado depois da crise e da conscientização ecológica em um fenômeno que ele chama de ambientalização.
} 
O termo condutor de turismo de aventura, ou somente condutor, foi forjado nesse contexto assim como é contado por J. J., que foi proprietário da primeira agência de turismo de aventura de Brotas e empresário do turismo por quinze anos:

O guia, guia turístico, era um profissional da Embratur que poderia não querer se envolver com aventura. Já o instrutor soava como alguém que fosse ensinar a técnica, e não tínhamos tempo para isso, além do que teria que ser alguém da Educação Física. Então, nos perguntando qual seria o melhor termo para aquelas pessoas que teriam uma atuação mais local e, ao mesmo tempo, envolvendo algum risco e habilidade esportiva específica, chegamos à palavra condutor. E nossa, como se discutiu! Tinham tantos fóruns, tantas discussões, ações do governo, capacitações. Nossa, como tinha debate! Tinha debate em todo lugar, para formular definições de tudo, desde o profissional até a definição de cada atividade, via internet, oficinas, encontros. Começou com o governo Fernando Henrique definindo ações e termos via Ministério do Meio Ambiente, depois mais diretamente com a aventura foi o Ministério do Turismo e a Abeta [Associação Brasileira de Ecoturismo e Turismo de Aventura, criada em 2004], trabalhando essas noções, e pra isso se usava muito a Adventure Sports Fair [evento realizado anualmente em São Paulo desde 1998 e que ainda é o espaço de reunião dos diversos agentes do lazer de aventura no Brasil].

Entretanto, passados aproximados vinte anos da criação das primeiras empresas especializadas nesses serviços na cidade, verifica-se ainda uma instabilidade conceitual e técnica bem como o descontentamento com as condições de trabalho. Isto porque, pode-se, pela primeira vez, vislumbrar as consequências que sofre uma geração incorporada por esse mercado e uma carreira toda dedicada à aventura nesses moldes.

Entre os profissionais de aventura das classes mais abastadas, as carreiras universitárias e o empreendedorismo são continuidades possíveis. Alguns se interessam por temas correlatos, como Biologia, Geografia ou Engenharia/Gestão ambiental. Mas as instituições de nível superior procuradas por aqueles que pretendem se manter em contato com o mercado da aventura são, na maioria das vezes, aquelas que dispõem de cursos de Turismo, de Educação Física, de Administração e de Publicidade, carreiras vistas como sucessoras possíveis da condução. Com o ingresso nas carreiras de Administração ou de Turismo, almejam ter seu próprio empreendimento, ocupar cargos 
de liderança ou de gerência nas agências de turismo e empresas associadas. Os que buscam carreiras em Propaganda, Publicidade e Marketing passam ao departamento de vendas ou de marketing das diferentes empresas.

No caso dos turismólogos e professores de Educação Física não empreendedores, aqueles que desejam continuar a conduzir procuram se tornar coordenadores de área. Ou seja, aqueles especializados em navegação em rios de corredeira coordenarão departamentos chamados de "Águas brancas" e aqueles especializados em tirolesa, arvorismo, escalada, rapel e/ou canionismo, coordenarão departamentos chamados "Técnicas verticais", forma como a maioria das agências turísticas de Brotas estão organizadas.

Entre os profissionais de aventura das camadas média-baixas, é comum que, após um período na condução, sejam buscadas outras carreiras concursadas, como tem ocorrido frequentemente com a de policial militar, bombeiro e bancário. As carreiras universitárias também têm sido acessadas, embora com menos frequência e com mais dificuldades no ingresso, pagamento (quando particulares) e deslocamento, já que, no período do trabalho de campo, não havia nenhuma faculdade na cidade. Mas, ainda é entendido que os cursos universitários não oferecem a qualidade técnica da aventura "na prática", dado também encontrado por Correa (2008), Paixâo (2009), Figueiredo (2011), Araujo (2012) e Auricchio (2013). O diploma superior, para aqueles que não tinham o suporte financeiro familiar ou a oportunidade de sair da cidade, pouco interferia na condição de trabalho com condução, e a formação universitária era demorada ou abandonada.

Muitas vezes, também, outras carreiras se tornavam simultâneas à condução, o que corrobora os dados de Araujo (2012), para quem, apesar da grande exposição na mídia e da crescente procura, estas carreiras não são rentáveis por sua sazonalidade: 
não são tão rentáveis, pois possuem uma demanda irregular que depende de condições climáticas favoráveis e por ocorrerem em períodos relacionados aos finais de semana, férias, dentre outros. Com essa particularidade, pode ser algo comum os profissionais que atuam nesse campo possuírem outra ocupação profissional, encarregada prioritariamente de garantir o seu sustento. Nesse contexto, sua atuação no lazer pode ser um trabalho e uma fonte de renda secundária (ARAUJO, 2012, p.70).

Neste sentido, certo 'malabarismo’ das carreiras era necessário, visto que a hora do trabalho com aventura era mais bem paga, por exemplo, que a hora/aula do professor de Educação Física ou o correspondente do bombeiro, mas a existência de clientes para aventura era esporádica. Isso faz com que na baixa temporada ${ }^{12}$ haja uma valorização de ocupações mais estáveis e na alta, a aventura seja preferida. No caso daqueles que cursam Educação Física, é comum trabalharem durante a semana em escolas, clubes ou academias, com carteira assinada, e continuar a conduzir nas férias, finais de semana, folgas ou "janelas", horários livres entre uma aula e outra ou entre um turno e outro.

Este era o caso de P.B. Um dia, muito nervoso em frente à sua escola de atuação, ele contou que lutava na reunião de planejamento para que suas aulas de Educação Física fossem aglutinadas de forma a permitir encaixar descidas ${ }^{13}$ para completar o orçamento. Mas, como a coordenação da escola resistia, ele não sabia o que era melhor, se continuar a dar aulas e auferir salário fixo e décimo terceiro, ou voltar a trabalhar exclusivamente com o rafting, já que cada descida pagava tanto quanto ou melhor do que seu turno escolar.

Neste artigo, entretanto, focamos a realidade dos profissionais de aventura que não seguem estes perfis. Ou seja, os condutores de turismo de aventura de baixa escolaridade, que não alcançaram acesso à formação universitária. Carnicelli Filho e

\footnotetext{
${ }^{12} \mathrm{~A}$ alta temporada em cidades turísticas corresponde aos meses de férias escolares. Especialmente, em Brotas, também aos meses de maior frequência de chuvas e em que o rio está mais adequado à prática do rafting, os de verão.

${ }^{13}$ Sinônimo de condução de rafting.
} 
Schwartz afirmaram, em 2005, que $60 \%$ daqueles que, chamaram os autores, de instrutores ou guias de rafting de Brotas estariam na faixa dos 17 aos 25 anos e $70 \%$ teriam como maior grau de instrução o ensino médio. Embora se note muitas combinações possíveis de níveis de escolaridade, classes econômicas e trajetórias de vida, em 2011, entre os profissionais da aventura em Brotas, aqueles que se consideram condutores de turismo de aventura, se confirmou a predominância do ensino médio, por vezes incompleto, como nível de educação formal e, por vezes, até ensino fundamental incompleto, como era o caso de C. J.:

Estudei até a oitava série só, né? E o que eu não gostava de estudar em escola... Por exemplo, geografia, eu não curtia muito, viajando com aventura eu fui obrigado a aprender. Até geologia, por causa dos tipos de rocha em que se pode fazer ancoragem... Fui obrigado a aprender sobre natureza, árvores, quais resistem mais, menos, biologia, fauna, flora do lugar, um monte de coisa. E acabei entrando de cabeça no que eu não gostava. E percebi que na verdade eu só não gostava daquele meio de estudar, né? Que tinha outro meio de aprender as coisas.

Outros perfis de trabalhadores práticos, que não se adaptavam ao universo escolar, buscaram Brotas como "escola de aventura". Ou seja, não só os nativos foram recrutados para a expansão do mercado de aventura, mas também pessoas naturais de outras localidades e egressas de outras carreiras. Muitos condutores referem o Exército Brasileiro como instituição de aquisição de conhecimentos e de atuação possível para aqueles que se identificam com os temas do desafio físico e exploratório e da sobrevivência na selva, que também são encontrados na aventura. Esta correspondência é relatada na literatura nativa. É senso comum que a corrida de aventura tem essa bagagem e existem narrativas que afirmam que o próprio rafting teria sido criado como estratégia de guerra. A. R. é um, entre outros, exemplos:

Eu sou de Leme, e eu gostava muito de acampar, ficar no meio do mato com os amigos de bairro, de escalar, de fazer rapel, adoro caminhar, fazer trilha. Aí surgiu essa paixão na prática, como esporte mesmo. Aí meu parceiro de escalada veio pra Brotas mais ou menos em 1992. E depois ele me trouxe junto e a gente começou a vir fim de 
semana, feriado, temporada, aí comecei a trabalhar, mas ainda meio como hobby, que era um jeito de fazer sem pagar, coisa que a gente não tinha equipamento pra fazer sozinho. Fiquei seis anos na Força Aérea, mas sempre tinha esse segundo emprego, onde eu unia o útil ao agradável. Aí resolvi largar e ficar só com o segundo emprego pela minha paixão pela natureza e pelos desafios diários e fiquei até agora. Cheguei aqui com cinco reais no bolso dormindo num quartinho de coisas de uma agência. Virei condutor de turismo de aventura, fui crescendo, consegui dividir o aluguel de uma casa com um amigo. Depois conheci minha esposa, virei coordenador, construí uma família e hoje estou abrindo minha empresa.

Neste contexto específico, o serviço militar obrigatório teria fornecido elementos para o posterior trabalho com aventura. E, na aventura, estas pessoas teriam encontrado a oportunidade de utilizar seu saber ambiental, disposição prática e condicionamento físico sem a conotação bélica, ou se submeter à disciplina hierárquica rigorosa do contexto militar.

Por outro lado, entre os condutores estão não apenas aqueles que já tinham experiência prévia com motivos e técnicas semelhantes àquelas da aventura e queriam transformá-la em ofício, mas também pessoas que se iniciaram na aventura a partir dos cursos de formação de condutores. Seja porque buscavam um emprego na cidade, ou porque gostariam de se tornar adeptos dessas modalidades como práticas de lazer, os cursos de condução oferecidos pelas agências foram a estratégia encontrada para a aquisição dos conhecimentos técnicos. Esse é o caso de D. E., que foi condutor e atualmente trabalha no departamento de vendas de uma agência turística:

Eu era técnico em química, mas o clima de São Paulo, o estresse, fez com que eu e minha família começássemos a procurar uma cidade do interior para morar. E alugamos uma casa aqui por seis meses para ver como seria. Aí eu comecei ver descerem o rio e a perguntar como fazia. Por que eu era molecão, queria brincar com os outros meninos adolescentes da minha idade, só que eu não sabia. Eles me disseram que tinha cursos que ensinavam, que eram cursos de condução. Mas, mesmo assim eu fui fazendo. Eu queria fazer por diversão, porque eu sempre gostei de esporte, eu queria brincar mesmo. Mas aí eu fui aprendendo primeiros socorros, como desvirar um bote, a ler linha d'água. Então, eu queria fazer isso para me divertir, mas era tanta informação que tinha que ter, que isso também poderia ser uma fonte de renda e eu pensei: melhor ainda! E eu comecei de uma hora pra outra, sem equipamento nenhum, não tinha nem roupa de neoprene e 
era inverno. Mas foi muito legal. Porque o curso foi bem intensivo e depois de uns cinco meses, eu já me sentia compreendendo a parte técnica.

Nos dois excertos anteriores, percebe-se uma ideia muito comum entre os condutores de aventura que incita à reflexão: embora o termo lazer não apareça com frequência na fala nativa, nota-se que a aventura era almejada como brincadeira, desafio prazeroso, divertimento, interesse e desenvolvimento pessoal, mas, por vezes, só foi atingida como trabalho e, por outras, se tornou trabalho, mas não deixou de ser isso tudo.

Apesar de o lazer ser considerado como vivência de não trabalho (MARCELLINO, 2013), entre os profissionais da aventura de Brotas, a divisão bem delimitada trabalho-lazer parece não se aplicar, assim como para os rafteiros de Queenstown estudados por Carnicelli Filho (2013), já que a condução é representada como uma mistura não só de esporte com turismo, mas também de lazer com trabalho. Como tais práticas são vividas pelos pesquisados quase como uma totalidade, tanto lazer, como trabalho, de forma semelhante ao que Wheaton (2004) e Carnicelli Filho (2013) chamam de estilo de vida, preferimos, neste texto, nos referir a este campo apenas como aventura, em sua acepção mais abrangente, já que a expressão lazer de aventura não é operada pelos pesquisados e porque para eles a aventura é também trabalho.

Neste sentido, Brotas tornou-se polo e passou a atrair não somente os turistas interessados em consumir uma aventura pontual e conduzida, mas também os que almejavam trabalhar com ela, porque procuravam vivê-la integralmente, e Brotas ainda é uma cidade que dispõe de bastante natureza para proporcionar isso. Ambiguamente, é por este mesmo motivo que a experiência em Brotas pode não se encerrar na cidade, 
pode ser expandida e pode levar à circulação, assim como sinaliza E. B., estudante de Turismo e condutor de técnicas verticais, no texto abaixo:

Eu fazia curso de Turismo e Hotelaria na faculdade em Santa Catarina e nunca tinha tido contato com aventura, aí tive a oportunidade de fazer um estágio com arvorismo. E como eu sempre gostei de mato, cresci em sítio, achei interessante entrar nesse ramo, porque durante a faculdade eu trabalhava de garçom e era sempre a mesma coisa. E eu sempre tive vontade de fazer uma viagem, assim meio louca, mais longa. Então, eu já tinha ouvido falar muito de Brotas, por causa do trabalho. Pesquisei e descobri que era um dos melhores lugares do Brasil pra trabalhar com isso. E deu certo de eu vir. Depois eu tranquei a faculdade porque eu quis ficar mais. E estou aqui há dois anos e dez meses agora. Aprendi a guiar primeiro tirolesa e boiacross, depois rafting e canionismo, coisas que eu nunca teria a chance de aprender talvez estando lá na faculdade. Eu nunca esperei tanto, tanta coisa que teve para aprender aqui, e que agora eu sei, e isso pode me abrir portas. Não é todo mundo que sabe fazer isso e, aonde eu for, eu vou ter esse diferencial de saber mexer com essas coisas. Porque é tudo muito novo no Brasil, vai crescer, né? $\mathrm{E}$ ano que vem eu volto pra faculdade para terminar, e aí, depois eu tenho vontade de ir pra Pucón no Chile trabalhar com isso, que lá também é um polo. Ou talvez Costa Rica que tem muito rafting e tirolesa, porque eu quero aprender o espanhol, né, e agora eu queria uma viagem pra fora do país.

Além de atrair investimentos de fora, Brotas passou a atrair pessoas de outras localidades que passaram a procurá-la para adquirir uma formação profissional em aventura, ou viabilizar uma vida de aventura que não seria possível com qualquer outro emprego, ou em uma cidade que não tivesse a disposição geográfica adequada à prática, ou porque seria mais caro viabilizar a aventura como opção exclusiva de lazer, ou como atleta competitivo, visto que não há esporte de aventura profissional no Brasil, assim como explicita P. Z.:

Minha profissão é uma consequência do conhecimento que eu tinha do esporte canoagem. Um meio que eu encontrei de usar meu esporte e conviver com a natureza no meu dia a dia. Fazer essa união, trabalhar, ter com o que sobreviver, mas não precisar deixar o meu esporte, o meu lazer e a natureza.

A proximidade ou semelhança de sua atividade laboral com a prática de lazer desejada, ou esporte, divide lugar com os temas do contato com a natureza, do desafio do risco que ela pode impor e da satisfação de proporcionar aos clientes um momento 
agradável, saudável, prazeroso e, por vezes, extraordinário. Mais uma vez, D. E. empresta seu ponto de vista para a explicitação dessa questão:

É importante atuar em uma empresa que tem relação com o meio ambiente, além de ter consciência e passar isso pras pessoas. E o turismo de Brotas começou justamente por causa da questão ambiental. Todo atleta e condutor de aventura tem uma cultura ambiental legal. Quem vive disso, sem excluir ninguém, do condutor ao empresário, tem paixão pela natureza. Seja a pessoa que tem um curso superior, ou que só tem primeiro grau, isso é o que se tem em comum, e é o que nos move a continuar trabalhando com isso, porque não é a questão financeira. Não tá dando dinheiro assim pra ser a questão financeira. É essa coisa meio mágica mesmo do trabalho com a natureza. Você nunca vai ver essas pessoas jogando lixo no chão, cortando árvore onde não pode. E Brotas é o grande exemplo disso. Foi passando realmente de um pro outro. E eu adoro ver meus filhos brincando de pé descalço, eu prefiro levar eles pra um ecoparque do que pra um parque de diversão tipo playcenter. E, além disso, tem muitas outras coisas envolvidas, como saber trabalhar com pessoas. A importância de você estar lidando com o sonho de alguém. As pessoas não vêm pra cá só descer um rio, mas pra se sentir um superatleta. Pra se livrar do estresse, mas também pra parecer um herói na frente do filho. E o próprio condutor é visto e colocado como um herói. Aquele que faz parte da história da vida dessas pessoas, em um momento que marca. Então, é como se você pegasse uma pessoa que nunca viu uma bola na vida e colocasse ela pra marcar o pênalti de uma final de campeonato e ela fizesse o gol. Mas, mais ainda que isso, numa arena em que ela pudesse não sair viva. Você leva a pessoa a ter emoções que ela não poderia ter sozinha. Isso é ser condutor de aventura.

A educação ambiental, como motivo e objetivo da prática e do trabalho com aventura, tem sido investigada, mas é tema para outro artigo. Cabe dizer aqui que Marinho (2004), entre outros autores, embora acreditem neste potencial das práticas de aventura, têm sido críticos da forma como elas vêm se desenvolvendo por não cumprirem criteriosamente com o compromisso que dizem ter com a sustentabilidade e não garantirem espaço e tempo na condução das atividades para ações educativas, o que faz perder a oportunidade de trabalhar o lazer como formação cidadã crítica e instrumento de transformação social (GOMES, 2008, MARCELLINO, 2013).

Além dos motivos relatados pelos condutores para a procura de tais atividades e suas conexões com questões contemporâneas, como o ambientalismo, é importante 
relatar que as entrevistas revelaram que muitos não só procuram a aventura como ofício, mas se vinculam também ao rafting competitivo, para poder viajar, justificar e, até, financiar a visitação de outros rios, cidades e países. Nessa perspectiva, é o rafting de campeonatos, e não o de expedição, que pode mobilizar recursos da prefeitura e/ou de patrocinadores. Como o lazer descompromissado não é incentivado formalmente, o pódio e sua visibilidade são contrapartida ao financiador, além da legitimação moral diante dos outros habitantes da cidade, que enaltecem o valor disciplinador e pró-saúde simplistamente conferidos ao esporte.

Em uma localidade na qual o lazer não é garantido à população e na qual o lazer de aventura é visto prioritariamente como nicho de mercado, aqueles que não são capazes de pagar por ele precisam criar contrações conceituais para vivê-lo. No caso do esporte competitivo somado à condução, criam-se jornadas adicionais de trabalho para viabilizar a aventura, na medida em que viajar é preciso para que seja uma aventura, já que a repetição de trajetos e a permanência em um mesmo ambiente diminuem a surpresa e o inesperado que a definem.

A população local em geral, que não trabalha com aventura, não conhece os lugares da prática de aventura que encontram-se dentro de fazendas privadas, com exceção do trecho urbano do rio Jacaré Pepira Mirim, e considera as atividades mediadas pelas agências caras. Os programas das Secretarias de Esporte, Turismo e Meio Ambiente não viabilizam o lazer de aventura para os cidadãos brotenses. A vivência do lazer de aventura somente está garantida de forma pontual, por meio de um evento denominado 'Dia do Turismo', de acordo com o estudo de Ribeiro (2012). No 'Dia do Turismo", instituído por lei em 2010 e por meio de uma parceria entre a Prefeitura Municipal e o setor privado, são sorteadas vagas e os moradores contemplados podem escolher um local que gostariam de conhecer e as atividades de 
aventura que gostariam de participar. $\mathrm{O}$ evento acontece uma vez por ano, durante somente meio período, no dia da padroeira da cidade.

Isso demonstrado, na convivência mais detida com nossos interlocutores, as narrativas mais romantizadas deram lugar àquelas menos glamorosas e às condições materiais de uma aventura precária (BANDEIRA, 2012). Dificuldades recorrentes também apareceram como constitutivas de suas vidas de aventura. Assim como relata M. L., jardineira e condutora de turismo de aventura usualmente em trilhas, arvorismo e tirolesa:

Eu sou de Goiás, morei no Distrito Federal, no Mato Grosso, mas, aí, eu estava trabalhando com coisas que não deram certo. Aí, eu tive a oportunidade de fazer dois cursos de condutor no Mato Grosso, já segundo as normas da ABNT, ou seja, isso é a profissionalização do turismo para os guias. E eu ouvia falar muito de Brotas, que aqui o turismo era profissional e eu vim. No primeiro e segundo dia, eu dormi no banheiro da rodoviária. Aí, depois, eu conheci o pessoal da agência e me deixaram ficar no barracão de equipamentos. Fiquei um mês lá e depois eu fui embora de volta pra Goiás. Aí, eu voltei de novo e dormi na rua outra vez, mas dessa vez eu continuei procurando emprego, perguntar, pedir, receber um não, um talvez, e na terceira semana eu já estava de carteira assinada. Mas fora do turismo, né, que no turismo não assina não. Então, eu sou jardineira durante a semana e condutora de aventura nos finais de semana, porque eu amo mesmo. Porque não dá pra pagar todas as contas só com turismo... Tem quem consegue, mas tem que se acabar de trabalhar, tem que saber guiar quase todas as atividades e isso quando aparece a oportunidade de trabalhar todo dia, porque aqui a escala roda, né? E por causa da baixa temporada fica sempre ruim. É mais fácil se sustentar de turismo quando é sozinho, eu acho, mas eu tenho duas filhas. Só que eu amo a natureza, eu amo o contato com a natureza, eu amo fazer trilha, fazer rapel, fazer arvorismo, acho que às vezes eu fico mais deslumbrada que o cliente.

Os condutores relatam que, além da baixa remuneração e da informalidade de sua atividade, as agências, ao oferecerem os cursos de formação, criavam relações de dependência e expectativa de fidelidade que passavam de gratidão à subserviência. Essa informalidade da atuação profissional é encontrada, também, em outros campos de atuação no lazer, como relatado pela literatura. 
Stoppa (1999), ao estudar acampamentos de férias no Estado de São Paulo, encontrou que muitos ex-acampantes atuavam nas temporadas de férias como monitores, em troca de qualquer remuneração, sem exigência de formação específica que os qualificassem para a atuação e, ainda, sem vínculo empregatício. A exigência era somente a disponibilidade para atuar e a ligação afetiva com a atividade exercida. Problemas também foram citados na pesquisa de Ribeiro (2006) com profissionais do lazer em navios de cruzeiros marítimos. Morar e trabalhar no mesmo espaço, extensa jornada de trabalho e o consequente pouco tempo para fruir o lazer, a falta de diversão dentro dos navios para os animadores, a discriminação sofrida por outros tripulantes, a falta do cumprimento da lei trabalhista brasileira e, ainda, a falta de treinamento antes do embarque foram alguns pontos negativos citados pelos pesquisados sobre a atuação profissional nos navios. Ou seja, a informalidade no trabalho com lazer não é exclusividade do contexto da aventura.

Carnicelli Filho (2006) também analisa mais especificamente as condições de trabalho no rafting e afirma que, assim como a de outros profissionais do lazer, os rafteiros optam por tarefas nas quais aliam o prazer decorrente da vivência destas atividades à remuneração. Embora esta também seja nossa impressão, falta ao autor perceber que não se trata de trabalhar por lazer, mas de buscar no trabalho uma modalidade que se pretendia de lazer, mas que é inacessível a determinadas classes e perfis sociais, por falta de políticas públicas que garantam seu acesso.

Para aqueles que tomam a condução como um emprego de juventude, que têm outros projetos e condições de implementá-los, a interpretação do autor parece adequada. Entretanto, para aqueles oriundos das classes baixas, o sentido pode ser outro, daí almejarem o fortalecimento de uma categoria profissional e também de lutarem pela profissionalização do rafting competitivo. A aventura, tal como é 
representada em Brotas pelos condutores, mesmo enquanto trabalho, é muitas vezes referida como prazerosa (BANDEIRA, 2012). Mas aqui cabe ressaltar a importância de confrontar as narrativas formais das entrevistas e questionários com as rotinas práticas para uma compreensão mais abrangente do objeto de estudo.

Se, por um lado, o enfrentamento do risco é tido como peculiaridade e divertimento na aventura, por outro lado, a etnografia permite perceber que, quando a aventura é problematizada enquanto trabalho, suas exigências podem ser vistas pelos condutores como uma demanda desgastante. Por exemplo, os condutores muitas vezes relatam insônia, ao saberem que o rio está cheio, por se sentirem responsáveis pelo que possa acontecer com seus clientes: "às vezes, eu nem durmo em dia anterior ao canionismo, é muita responsabilidade trabalhar com a vida das pessoas, é gratificante pelo que elas sentem, mas elas não fazem ideia da tensão que a gente passa” (A. B.).

Esses dados nos levam a advogar contra o uso das expressões risco imaginário, risco simbólico e simulacro de risco, pois demonstramos que embora calculado e gerido, o risco nestes contextos não é uma invenção ou expectativa e sim uma concretude, que preocupa o condutor. Isto corrobora dados dos cento e vinte um condutores de aventura estudados por Paixão et al. (2011), em Minas Gerais, para quem as atividades de aventura são situações de risco, e sua minimização se dá pela excelência técnica, condição dos equipamentos e informações ambientais/climáticas. Assim como Carnicelli Filho (2006), quando afirma que o sentimento de responsabilizar-se pelo cliente é tensionado ainda mais pela forma como se converte em comprometimento com a agência empregadora:

[...] além de vivenciarem por si mesmos as fortes emoções de uma atividade de aventura, devem zelar pela segurança dos clientes das agências e garantir que esta seja uma atividade agradável, segura e prazerosa, para que eles voltem a procurar aquela respectiva agência (p. 254). 
Schwartz e Carnicelli Filho (2006) afirmam que ansiedade e tensão são evidenciadas pela necessidade de se garantir a segurança. Os autores afirmam que lidar com as próprias emoções e com as dos clientes representa o maior desafio apontado pelos profissionais em seus questionários e que eles necessitam e desejam complementação e atualização de sua formação. Correa (2008) e Auricchio (2013) encontraram que estes tipos de profissionais apontam como conteúdos mais importantes de sua formação, junto das habilidades técnicas específicas de cada modalidade, os primeiros socorros/resgate e a gestão de segurança.

Em Brotas, segundo Bandeira (2012), para endereçar tais questões e para minimizar a fragilidade das condições de trabalho dos condutores ante as agências, foi idealizada a Associação Brotense de Condutores de Turismo (ABCT). A ABCT ficaria incumbida do treinamento e da atualização da formação dos condutores e as agências contratariam os serviços da Associação. Dessa forma, a Associação equacionaria melhor e tornaria mais despersonalizada a tarefa de arregimentação dos condutores e a administração da escala de trabalho, bem como cumpriria estipular uma espécie de piso do serviço prestado e evitaria os constrangimentos impostos pelas agências. Assim como narra A. S.:

Quando foi criada a associação, pelo que eu sei, foi ideia daquele mais velhinho, e muitos abraçaram a intenção que era ter uma central de guias. Pra todas as agências quando precisassem de guia ligar lá e a central mandar o guia. Pra agência não poder escolher, não fazer desfeita pra um, privilegiar o outro, pagar diferente. E pra todos poderem descer pra mais de uma agência, porque às vezes a gente não tá na escala daquela agência naquele dia, vai ficar sem ganhar, mas ela também não quer que a gente desça pro concorrente dela, entendeu? Mas, aí, ficou meio assim, porque tem instrutores que não gostam de uma agência, têm birra com outro condutor que é coordenador de outra, e acho que foi por esse ponto que não funcionou.

O projeto da Associação não se desenvolveu a contento e ela atuou junto à Prefeitura, sem a autonomia inicialmente pretendida. Nos anos de 2011 e 2012, a 
Associação auxiliou na realização do II e III Seminário Técnico em Condução de Aventura, políticas para condutores atuantes e residentes em Brotas, com o objetivo de padronizar sua atuação independentemente da agência de vínculo e atualizá-los em relação aos novos protocolos e exigências, principalmente normas da Associação Brasileira de Ecoturismo e Turismo de Aventura (Abeta), que organizou o primeiro Seminário Técnico em parceria com a Associação Brasileira de Normas Técnicas (ABNT), e de prepará-los para a alta temporada, momento em que os problemas se acentuam pelo aumento no número de clientes e operações e também pela aumento das chuvas, volume de água do rio e consequentemente, do risco.

Voltando à reflexão sobre a lida com o risco como um dos elementos principais da atuação desses profissionais, é importante relatar que há situações eventuais nas quais os condutores eram persuadidos a aceitar clientes que estavam acima do peso, ou abaixo da altura permitidos pelas normas ABNT, a operar com um grupo maior que o recomendado em determinada atividade, a iniciar a operação em horário inadequado, com o nível do rio muito alto, ou muito baixo, e até a participar de atividades para as quais não se sentem preparados para operar na falta de outro condutor mais experiente.

Essas situações, embora não frequentes, aconteciam tanto por imposição direta dos donos das agências, no sentido de não perder clientes ou de agradar a um amigo ou parente, bem como por influência do coordenador da atividade, por não querer comunicar ao proprietário da agência que cometeu um erro de escala, ou que não dispõe de funcionário apto para determinada operação. Essas situações são mais tensas nas atividades em que há exposição a ambientes naturais mais desafiadores e que são consideradas por eles mais complexas, portanto mais arriscadas, como o rafting, mas principalmente o canionismo. 
Segundo dados de Bandeira (2012), na espera por um canionismo, uma conversa entre um condutor e o coordenador da atividade ilustra este ponto. O primeiro dizia pensar que a atividade para a qual foi recrutado se tratava de uma tirolesa e que ele não se sentia confortável para fazer um canionismo. O coordenador argumentou, por sua vez, que ele só faria a segurança e não a ancoragem $^{14}$, que tal procedimento consistia numa ação "simples", e que, como ele mesmo o havia treinado, sabia que era capaz. Ele pediu pra que o coordenador escolhesse outra pessoa. O mesmo foi até a recepção e fez algumas ligações, mas ninguém estava disponível. Relutando muito, o condutor acompanhou a equipe até a base de operação, mas se trancou em um pequeno cômodo dentro do barracão de equipamentos, dizendo estar muito nervoso. A equipe de condutores, do outro lado da porta, tentava assegurar a ele que ele era capaz de fazer a assistência, porém, resistente e contrariado, saiu e seguiu para longe com as mãos na cabeça. Nesse momento, uma condutora que voltava com um grupo que havia realizado uma trilha ouviu os apelos do coordenador da atividade para que o substituísse e, diante da insistência do pedido, que vinha, também das outras pessoas da equipe, acabou aceitando a tarefa. Durante a atividade, um cliente deixou que sua jaqueta se aproximasse do freio que o atrelava à corda e ficou preso no meio da descida. $\mathrm{O}$ coordenador da atividade teve de realizar um resgate, fato que gerou uma tensão adicional à operação. Ao perguntar a eles porque a negação em atuar se conformou foi mencionado que o canionismo tem menos pessoas capacitadas e as condições informais de trabalho e a baixa remuneração fazem com que muitos condutores experientes não

\footnotetext{
14 'Fazer a segurança' significa controlar do chão a velocidade e descida do cliente pelo rapel, ao manejar um freio capaz de segurar e soltar a corda de descida, que é acoplada ao equipamento do condutor. No canionismo, além daquele que faz a segurança, é preciso haver aquele que faz a ancoragem, ou seja, que por meio de nós posiciona a corda no topo da cachoeira e acopla o cliente a essa corda, posicionando-o para a decida. A segunda tarefa é tida como mais complexa e é designada aos condutores mais experientes, que são usualmente os coordenadores da área.
} 
possam se dedicar exclusivamente a aventura, o que os deixa indisponíveis quando há procura pela atividade sem agendamento prévio.

Os proprietários das agências, por sua vez, relacionam as situações de coação às dificuldades do empreendedorismo, que julgam ser custoso no Brasil. Entre as dificuldades mencionadas, queixas comuns entre empregadores, são os custos trabalhistas que tornam impossível a manutenção de funcionários registrados, bem como as oscilações da economia, a sazonalidade do turismo e a dita concorrência considerada "desleal" por parte de agências que ofereceriam o serviço por um preço muito inferior, sem investir da mesma forma na formação de condutores e na qualidade e na manutenção dos equipamentos. Outra queixa que recai diretamente sobre os condutores é que os proprietários e administradores de agências criticam sua suposta falta de comprometimento e evasão constante. Esta conduta é naturalizada muitas vezes sob a égide do espírito aventureiro. Ao procurar por um condutor específico em uma agência, pode-se ouvir da recepcionista:

Ele não trabalha mais aqui não. [E você sabe onde eu posso encontrálo?] Ih minha filha, eles têm espírito aventureiro. Eles não param não. Trabalha um pouco, vai viajar. Ele estava na Argentina semana passada, agora estava aí, mas não sei se já foi embora de novo e nem pra onde...

O espírito aventureiro é, portanto, coragem, desapego, vontade de viajar. Entretanto, quando perguntados sobre o porquê da circulação, os condutores referem não somente disposição em circular, mas principalmente o descontentamento com as condições de trabalho, tais como a baixa remuneração, os vínculos informais, o desacordo com os protocolos de operação e o autoritarismo das relações hierárquicas. Essas narrativas frequentes em Brotas no período da pesquisa não corroboram a afirmação de Carnicelli Filho (2005) sobre os trabalhadores de rafting, quando ele afirma que, mesmo com a ansiedade e a tensão inerentes à sua tarefa, os guias se 
mostram alegres e confiantes nos momentos que antecedem as atividades. Ora, se o próprio autor identificou que os condutores se responsabilizam por proporcionar prazer aos clientes, por parecer sempre alegre, sereno e/ou controlador de todos os riscos pode ser uma autoimposição, recurso para a execução satisfatória do trabalho ou, exigência dos proprietários das agências, como protocolo de atendimento ao cliente, que os querem sempre solícitos e dispostos diante dos turistas.

Marcellino et al (2007) apontam que este fato se trata de uma "personalidade profissionalizada". Ou seja, segundo a crítica dos autores, alguns profissionais do lazer, e acrescentamos, aqui, da aventura, acreditam que o bom humor é tão importante que, por vezes, se torna melhor avaliado do que a competência. Ainda de acordo com suas palavras, muitas vezes a amabilidade acaba por desviar a atenção do público das deficiências de serviços da organização de lazer e o profissional se apresenta como se fosse um "bobo da corte". Marcellino et al. (2007, p. 16) salientam que o bom humor é importante, "mas não pode representar a ausência de competência, compromisso político e seriedade. Esses são os três elementos que tornam o exercício da profissão digno." Cater eCloke (2007), em sua análise sobre Queenstown, considerada a capital neozelandesa, senão mundial, da aventura, sinalizam para um processo semelhante ao descrito para o caso de Brotas:

[...] guias, que são os porteiros da negociação dessas experiências. Os clientes têm uma idéia esperada da pessoa que irá levá-los através da atividade [...] Esta imagem é reforçada pela empresa e publicidade; em um dos exemplos mais flagrantes que encontramos, um anúncio publicitário para um passeio de jetboat divulga o piloto como sendo "personalidade plus", referindo-se claramente aos seus caracteres distintivos [...] A evidência sugere que os operadores de aventura procuram empregar pessoas que estejam em conformidade com um determinado tipo de olhar que corresponde às expectativas do turista. Além disso, esses guias, sem dúvida, complementam o desejo de 'boa aparência' durante a prática da atividade (p. 15). 
Esta aparência não está relacionada apenas com o corpo atlético ou o estilo das roupas do profissional de aventura, mas também com como ele aparenta lidar com o risco e o medo. Esta questão é o foco do estudo de Carnicelli Filho (2013), especificamente sobre os condutores de rafting em Queenstown. Ele afirma que a necessidade de criar experiências emocionais, vinculadas a percepção do risco e medo são valores dominantes nas empresas que trabalham com atividades de aventura. Ao passo que o cliente precisa sentir medo e apreensão, os guias não podem demonstrar seus próprios, com nervosismo e hesitações. $\mathrm{O}$ autor relata que quando isso aconteceu em seu campo houve reclamações dos clientes.

A imprevisibilidade nas práticas de aventura, nem sempre são simulacros, como sinaliza parte da literatura sobre o tema no Brasil, muitas vezes são reais não só para estimular o cliente, mas porque novas e surpreendentes para o guia, que não pode controlar o ambiente no qual atua. Carnicelli Filho (2013), chama estas situações de jogo emocional ou performance emocional, mas ao afirmar que em vez de gerenciar emoções puramente porque a organização está pagando por um comportamento específico, esses guias de aventura o fazem tanto para satisfazer suas aspirações pessoais de viver como guias, como também a dos clientes, porque são eles que viabilizam esse estilo de vida, o autor perde a oportunidade da reflexão crítica. Além disso, ao priorizar na descrição situações vividas em bares e momentos de descontração, ao afirmar que os condutores utilizam seu repertório aventureiro eficientemente para se diferenciar positivamente no flerte e justificar seu estudo sobre as emoções sentidas e expressas pelos condutores de aventura, por sua importância para o empreendedor, já que, segundo o autor, perder a capacidade de administrar as emoções de medo e ansiedade afeta diretamente a experiência do turista e o andamento dos negócios, o autor negligencia as dificuldades e problemas dos condutores. 
Tendo a crítica como objetivo, Bandeira (2012) permitiu perceber momentos de pouca descontração, nos quais o tédio e o descontentamento, mesmo diante dos clientes, davam a tônica da atividade profissional. Numa das descidas de rafting, foi possível presenciar o descontentamento de um condutor que, no seu juízo, considerava os clientes daquele momento muito ruins, porque não habilidosos para mínima manipulação dos remos e tampouco prestavam atenção às suas instruções. Tal desagrado era externado sem meias palavras: "Olha, mas que saco, viu, vou fazer força sozinho mesmo, para chegar logo e acabar essa tortura!” (P. B.).

Estes dados sugerem fortemente que a rotinização da aventura como atividade turística regular faz com que o tom que por muito tempo sustentou as narrativas excepcionais em torno dela ganhe dimensões de uma atividade estafante, norteada por relações trabalhistas tensas. As condições pouco ideais de sua execução, enfim, são problematizadas pelos próprios condutores:

O pessoal tá cansado. Não tem mais tanta alegria, sabe? Não sei se é exaustão do tanto que a gente faz força, tem que carregar e descarregar tudo, todo dia, às vezes três vezes por dia [um bote de rafting pesava em torno de 95 kilos]. Dói a coluna, ombro, pulso, hérnia. Ou é pressão que vem de cima. Porque agora tem que fazer papelada pra tudo, contar e recontar tudo, assinar um monte de papel diferente, e não pode esquecer de nenhum, por causa da regulamentação. Ou é porque o dinheiro é ruim e a gente vai se decepcionando. O pessoal tá cansado de ter que fazer três descidas por dia com o rio baixo. Porque o cliente não entende, ele acha bom, mas pra gente não dá mais a mesma vontade, o bote vai devagar, fica parando em tudo que é pedra, não dá pra curtir. E aí o trabalho perde a parte de bom que tinha em comparação aos outros trabalhos, que era a gente se divertir trabalhando. E até alguns clientes, que já fizeram outros raftings em cheia, acham meio sem graça e a gente fica meio assim com vergonha e perde aquela integração boa que pode ter com o cliente. Vira esporte de linha de produção, perde a adrenalina (MM).

Dados de Ribeiro (2012) mostraram que os condutores participantes no

Conselho Municipal de Turismo estavam também descontentes com a não implementação da lei que se propunha a criar o Serviço Municipal para o Turismo 
Sustentável, um Sistema de Controle de Visitação Turística por meio de voucher ${ }^{15}$, cujo propósito seria permitir ao poder público limitar o número máximo de turistas, diária, mensal ou anualmente, permitidos pelo estudo de impacto ambiental, em um determinado atrativo turístico natural. Para os condutores, o rio Jacaré-Pepira, onde o rafting acontece, já apresentava impactos ambientais negativos (lixo e assoreamento eram os mais citados) e o número indeterminado de agências e botes em alta temporada dificultava as operações. Mas os empreendedores, donos das agências, para quem não é interessante limitar o número de clientes, se opunham. Este dado está de acordo com Agnelli (2006), que critica Brotas por usar os adjetivos "eco" e não respeitar tais prescrições de sustentabilidade.

Tais tensões contrastam com visões mais idealizadas da prática de aventura, tais como as descritas por Souza (2004) em seu estudo de mestrado realizado na área da Educação Física, mas informado pela Psicologia social e os estudos do imaginário. A autora afirma que a solidariedade é a tônica do rafting:

É pela solidariedade que temos a oportunidade de sair do utilitarismo para entrar na gratuidade e assim acontece no rafting. Cada pessoa que está no barco procura dar o melhor de si, realizando as manobras [...] conforme manda o instrutor, com a intenção de solucionar o problema de todos, que é o deslizar pelo rio e passar pelas corredeiras com o máximo de segurança, alegria e prazer. Mas, na realidade, o mais solidário dentro dessa atividade esportiva são os instrutores (guias) pois eles detêm um conhecimento que passam para os ocupantes do bote, com o intuito de solucionar os problemas de adaptação dos participantes da atividade (p. 96).

Do nosso ponto de vista, aquilo que (aqueles que ela chama indefinidamente de guias ou instrutores) estão fazendo é trabalho: a venda de sua expertise técnica e condicionamento físico enquanto serviço. Não há dados nestas circunstâncias para uma discussão sobre solidariedade. Os condutores proferem comentários sobre clientes

\footnotetext{
15 Documento emitido que comprova junto ao prestador de serviço determinada reserva e o seu pagamento (BOITEUX; WERNER, 2009, p. 149).
} 
'preguiçosos', 'desengonçados', 'frescos' ou 'fracos' que a autora ignora. A partir dos dados deste estudo, não se pode afirmar que, como quer a autora: "Os discursos dos praticantes de rafting mostram que todo o esforço empregado durante a descida é compensado com muita alegria e diversão" (SOUZA, 2004, p. 119). Nem sempre é assim.

Além disso, (SOUZA, 2004) afirma que o rafting tem por característica a intencionalidade zero, segundo ela, "a não ser a conquista do prazer momentâneo". Entretanto, não foi isto que constatamos entre os condutores de Brotas que referem como suas maiores motivações para a adesão ao rafting: a) empregarem-se, e b) tornarem-se atletas, tanto para vivenciar o que chamam de prazer em representar seu país ("levar nossa bandeira lá pra fora", "por o Brasil no pódio”) e a vitória ("ser os melhores naquilo que fazem", "provar para quem não acreditou que podem ser os melhores do mundo"), como para viabilizar sua vontade de viagens. Segundo alguns deles, não fosse o rafting competitivo, por estarem cercados de pedágios, nunca teriam condições financeiras para sair de Brotas, quanto mais visitado outros países.

Embora essas características sejam enaltecidas como aquilo que "faz valer a pena" trabalhar com condução de aventura em Brotas, quando o cotidiano consiste em deslizar corredeiras, o prazer está mais concentrado no trocar de rio, ou em fruir o rio cheio, para tanto aqueles fluentes em inglês, segundo Carnicelli Filho (2013) podem aderir a um estilo de vida de circulação entre diferentes lugares do mundo conforme suas altas temporadas (o que não só significa maior remuneração pelo número de turistas, como novo e maior desafio técnico e fruição pela cheia dos rios) o que raramente acontece entre os condutores de Brotas. Os últimos chamam o fruir o rio, sem ser por trabalho, nem por competição, de fazer um bote de balada, ou seja, descer o rio pelo prazer do desafio físico. Para aqueles que não possuem equipamentos próprios (a 
maioria) usar o material da agência nestes casos é permitido por seus donos, usualmente quando estão satisfeitos com seu trabalho e se acompanhados pelo coordenador de atividades.

Assim como o rafting no rio Isère, em Savoie, na França, embora oferecido no modelo de cursos, a descida de um mesmo rio pode ser percebida em Brotas como monotonia pelo condutor experiente, principalmente na baixa temporada, embora a repetição de trajetos seja uma prescrição de segurança para o cliente leigo:

os grupos de águas brancas de uma empresa sempre vão entrar no rio, no mesmo lugar, navegar ao longo das mesmas trajetórias, parar nos mesmos locais, e descer na terra, da mesma forma. Esta forma muito rigorosa de "moldar" produtos comerciais de águas brancas pode ser considerada como uma verdadeira normalização da atividade. No entanto, esta restrição espacial das atividades dos instrutores não vem da ignorância do que o rio tem para oferecer [...] Se essa padronização é operada de forma sistemática, é porque ele oferece muitas vantagens. Ele permite a antecipação de dificuldades técnicas e uma quantidade suficiente de tempo para as manobras necessárias para ser concluída até por clientes inexperientes. Ele sempre usa os mesmos locais que são reconhecidos de forma permanente, o que é importante em um ambiente onde diversos objetos submersos, transportados regularmente pelo rio, podem ser perigosos para a navegação. Também distribui tacitamente os clientes e evita a superlotação de certos pontos de parada (MOUNET, CHIFFLET, 2003, p. 275-276).

Outra questão, ou preocupação bastante recente para os condutores de aventura, na medida em que o próprio campo da aventura nestes moldes é novo no Brasil e visto que a primeira geração de condutores de Brotas está chegando à faixa dos trinta aos quarenta anos de idade, é a aposentadoria e sua relação com os referidos cansaço e desgaste do corpo. Arriscamo-nos a dizer que a carreira do condutor, assim como, de modo geral, a dos atletas de alto rendimento, é abreviada pelas lesões e que sua recolocação no mercado da aventura é difícil. Segundo L. S., condutor de rafting, coordenador de águas brancas, criador, capitão e técnico da equipe brasileira mais vitoriosa em campeonatos nacionais e internacionais, além de instrutor da escolinha de rafting da Associação Brotense de Esportes Aquáticos: 
Eu acho que só dá pra guiar no máximo até cinquenta anos, que é a idade que o condutor mais velho que a gente conhece aqui tem. Mas, isso sem competir, porque se competir aí já dá bem menos, porque no meu caso além de trabalhar eu compito, e já estou cheio de lesão, acho que só aguento mais dez anos. Todo mundo que compete tem lesão, lesão cervical, lombar e torácica, ombro. E só vi aposentar por idade ou invalidez aqui. Só tem dois que pagam autônomo.

Os profissionais da aventura vêm percebendo algo que já é senso comum no pugilismo (WACQUANT, 2002), que, para além da boia, do remo, da corda e do bote, o corpo é seu principal instrumento de trabalho. É preciso usá-lo sem levá-lo à lesão irreversível porque, no final das contas, são anos investidos na aquisição de um capital corporal que é dificilmente convertido em outro tipo de capital:

Há um modo de compreensão totalmente particular, em geral esquecido nas teorias da inteligência, e que consiste em compreender com o corpo. Há uma infinidade de coisas que aprendemos somente com o nosso corpo, aquém da consciência, sem ter palavras para exprimi-lo (BOURDIEU, 1990, p. 219).

Carnicelli Filho e Schwartz (2005), por sua vez, se questionavam pertinentemente sobre a outra ponta da linha cronológica. Referiam que jovens com menos de 18 anos eram frequentemente recrutados para o trabalho. Verificamos que, atualmente, há uma maior preocupação com esta questão, os menores de idade passaram a ser incorporados como assistentes, aprendizes ou estagiários nas operações. Entretanto, apesar de exceções, há situações em que eles podem atuar eventualmente como condutores, principalmente aqueles mais altos e fortes, e que são reconhecidos como habilidosos, por exemplo, num dia de rio baixo, em que não haja outro condutor maior de idade disponível, com menos clientes dentro do bote e acompanhado por condutor mais experiente, conduzam o bote à sua frente.

Mas, no início do processo de transformação de Brotas em destino turístico e de criação das agências, a maioria dos condutores de Brotas relata trabalho muito precoce na condução, consequência de sua prática de boiacross por lazer. Como nos conta A. S.: 
Eu fazia boia, descia por descer, né? Aí, o cara da agência falou: - Já que você tá descendo por descer mesmo, já sabe descer, desce trabalhando, leva umas pessoas com você, que você me ajuda e desce ganhando. Aí, eu comecei, e era pivetinho ainda e olhava bastante os caras mais velhos fazendo rafting. Aí, eu cresci um pouco e também quis fazer. Fui vendo que o rafting dava mais dinheiro. Aí, eu fiquei só no rafting. Aí, me chamaram pra minha primeira competição com a equipe, e eu fui pra conhecer. Eu tinha acho que uns quatorze anos. Da minha equipe, eu era o mais novo, mas eu fui e já gostei. Aí, comecei a trabalhar, competir, mas nada muito sério. Aí, depois eu saí de lá e fui pra outra, que era a agência com quem a Canoar tinha parceria e atuava. Então, eu conheci caras que competiam bem mais sério, bem mais forte no Brasil, que eram da equipe Canoar Master. Eles já tinham ido pro mundial e todos os dias eu ficava olhando fotos dos caras. Aí, eu também quis aquilo pra mim. Antes essa coisa de idade era mais misturada. Antes não era um problema trabalhar sendo menor de idade. Mas, depois de um tempo, 2002 ou 2003, já tinha que ser maior pra descer com cliente ou acima de dezesseis emancipado. Porque começou a ter muita procura, o rafting começou a ficar muito exposto e teve que ser mais organizado. E tinha muita criança fazendo. E, aí, os donos de agência começaram a pensar, vai que acontece alguma coisa, né? Quem vai ser responsabilizado? Vamos andar no caminho certo, ter regras. E os condutores mais velhos já decidiam meio que assim: se o rio tá muito cheio, não dá pros mais novos descerem e depois eles decidiram não descer com cliente nenhum mesmo.

Neste sentido, Carnicelli Filho e Schwartz (2005) se referia à falta de entidades responsáveis que regulassem estas situações e garantissem melhores condições de trabalho, remuneração e oportunidades para os trabalhadores do rafting. E, ao considerar as informações dos cursos de formação oferecidos pelas agências insuficientes, os autores estranhavam que não houvesse um órgão institucional competente para garantir a adequação das capacitações.

Em 2004, a Associação Brasileira de Ecoturismo e Turismo de Aventura (Abeta), por iniciativa dos empreendedores já atuantes no ramo, foi criada, em parceria com o ministério do Turismo, o Inmetro e a ABNT com este papel. Ela se propôs a consultar grupos de profissionais já atuantes para discussão e padronização dos protocolos de operação de tais atividades. O que não significa que ela encontre aceitação absoluta. Em 2005, um conjunto de entidades esportivas contestou por carta 
enviada ao Conselho Nacional de Esporte (CNE) a legitimidade do trabalho da Abeta e a adequação de suas normas e exigiu um posicionamento do Ministério do Esporte em reivindicar para as associações e confederações existentes, visto o princípio constitucional da autonomia esportiva, o direito de regulamentação do campo da aventura não como um todo, mas cada instituição responsável por sua modalidade específica. Baseados no argumento de que órgãos nacionais de representação e de organização de algumas modalidades já existiam antes da criação da Abeta - e que, pela atividade física vigorosa implicada em sua prática, a aventura seria esporte - e não foram consultadas para a confecção das normas ABNT. Tal ação culminou com a criação da Comissão de Esporte de Aventura no Ministério do Esporte.

Além disso, segundo estes dirigentes e Auricchio (2013), as normas técnicas elaboradas pela Abeta versam sobre conteúdos superficiais para algumas modalidades e não aprofundam conceitos como lazer e educação ambiental. Segundo o mesmo autor que realizou estudo comparativo entre Socorro, Boituva e Guarujá, as normas da ABNT ou da Abeta não são implantadas na formação dos profissionais das duas últimas cidades, visto que suas modalidades principais (respectivamente, o paraquedismo e o surfe) não são contempladas pelas normas.

Por pelo menos uma década, embates em torno da questão "seria aventura esporte ou turismo?" impediram avanços nos processos de formação de profissionais de aventura, na medida em que iniciativas dos agentes do turismo e do esporte são concebidas como excludentes. Entretanto, o campo dos esportes se ressente mais, na medida em que a entidade do turismo recebeu importante verba de seu ministério e foi capaz de produzir material em larga escala e implementar um programa nacional chamado Aventura Segura, enquanto o Ministério do Esporte prioriza o futebol profissional masculino e os esportes olímpicos com sua reestruturação para sediar os 
megaeventos esportivos de 2014 e 2016 e oferece pouco suporte às modalidades de esporte de lazer, quanto mais aquelas de aventura. Este quadro fez com que a Comissão de Esporte de Aventura interrompesse sua atuação ainda em 2007.

\section{Considerações Finais}

Neste contexto da primeira proletarização da aventura no Brasil, podemos concluir que os condutores de Brotas vivem problemas semelhantes aos de outros lugares do país e do mundo e aos de outros profissionais do lazer, tais como a formação controversa e insuficiente, a informalidade da atuação e a baixa remuneração, agravados pela lida com o risco inerente à atividade. Propomos, então, que o risco não é apenas imaginário e simbólico, como se viu na demonstração etnográfica. Por outro ponto de vista, a profissionalização no âmbito da condução de aventura abriu um caminho, ainda que precário no setor de serviços, que viabilizou a prática como lazer e/ou esporte competitivo por frações das classes menos favorecidas.

A não dissociação clara entre esporte, turismo, lazer e trabalho, observada no campo deste estudo, embora muito criticada por diversos autores dos estudos do lazer, é operada na vida prática dos residentes de Brotas aqui estudados, pois é a única alternativa para certos perfis de pessoas viabilizarem a aventura. Isso dificulta a resolução do conflito entre entidades do esporte e turismo, e considerar os profissionais da aventura trabalhadores do lazer pode ser o caminho.

Entretanto, devido à sua especificidade, a capacitação do profissional de aventura precisa ser prática e no ambiente de atuação, o que os cursos de ensino superior, seja em Lazer, Turismo ou Educação Física, ainda não podem oferecer. Portanto, além de incorporar os conteúdos da aventura nos currículos do ensino superior, é preciso valorizar os saberes não institucionalizados dos agentes sociais 
nativos dos locais propícios para as diversas práticas de aventura e também melhorar a qualidade dos cursos técnicos intensivos oferecidos tanto por entidades esportivas quanto por seus empreendedores, em uma formação transdisciplinar e multisituada que preferencialmente deveria combinar estas diversas fontes de informação e experiência. A remuneração e condições de trabalho destes profissionais deve, portanto, ser condizente com tamanho investimento e dedicação demandada devido à complexidade do setor e considerar adicionais de periculosidade. Os dados deste artigo nos levam a concluir, então, que para superar os problemas do campo, é preciso um reconhecimento mútuo e trabalho colaborativo entre os diversos perfis de profissionais da aventura.

\section{REFERÊNCIAS}

AGNELLI, S. A. C. A Implementação da atividade turística em Brotas - SP: euforia e declínio. Dissertação (Mestrado em Desenvolvimento Regional e Meio Ambiente) Centro Universitário de Araraquara, UNIARA, Araraquara, 2006.

AURICCHIO, J. R. Formação e atuação profissional em atividade de aventura no âmbito do lazer. Dissertação (Mestrado em Educação Física) - Universidade Metodista de Piracicaba. Piracicaba, 2013.

ARAUJO, J. A. Formação de profissionais que atuam com esportes e atividades de lazer na natureza no entorno da cidade de Belo Horizonte/MG. Dissertação (Mestrado em Estudos do Lazer), Universidade Federal de Minas Gerais, Belo Horizonte, 2012.

BANDEIRA, M. No galejo da remada: estudo etnográfico sobre a noção de aventura em Brotas, SP. Dissertação de mestrado em Antropologia Social. Universidade Federal de São Carlos, 2012.

BETRÁN, J. O. Rumo a um novo conceito de ócio ativo e turismo na Espanha: as atividades físicas de aventura na natureza. In: BRUHNS, H. T.; MARINHO, A. (Org.). Turismo, lazer e natureza. São Paulo: Manole, 2003. p. 157-202.

BOITEUX, B. C.; WERNER, M. Introdução ao estudo do turismo. Rio de Janeiro: Elsevier, 2009.

BOURDIEU. P. Programa para uma sociologia do esporte. In: BOURDIEU, P. Coisas Ditas. São Paulo: Brasiliense, 1990.

BROTAS. Almanaque cultural de Brotas. 2012. 
CARNICELLI FILHO, S; SCHWARTZ, G. M. Guias de Rafting: perfil e emoções. Lécturas educación física y deportes, Buenos Aires, Año 10 - n. 85, 2005.

. Trabalho, responsabilidade e emoção: a adaptação de instrutores de rafting. In: SCHWARTZ, G. (Org.). Aventuras na natureza: consolidando significados. Jundiaí: Fontoura, 2006. p. 253-262.

The Emotional Life of Adventure Guides. Annals Of Tourism Research, n. 43, 2013, p.192-209.

CAMARGO, L. O. de L. O que é lazer. São Paulo, Brasiliense, 1992.

CATER, C.; CLOKE, P. Bodies in action: The performativity of adventure tourism. Anthropology Today. v. 23, n.6, dez, 2007, p.13-16.

CLIFFORD, J. A experiência etnográfica: antropologia e literatura no século XX. Rio de Janeiro: Editora da UFRJ, 2008.

CORREA, E. Formação do profissional de educação Física no contexto das atividades físicas de aventura na natureza. Dissertação (Mestrado em Ciências da Motricidade), Universidade Estadual Paulista, Rio Claro, 2008.

COSTA, V. L. Esportes de aventura e risco na montanha: um mergulho no imaginário. São Paulo: Manole, 2000.

DIAS, C.; ALVES JR. E. Entre o mar e a montanha: esporte, aventura e natureza no Rio de Janeiro. Rio de Janeiro: Editora da UFF, 2007.

DIAS, C.; MELO, V. A.; ALVES JUNIOR, E. Os estudos dos esportes na natureza: desafios teóricos e conceituais. Revista Portuguesa de Ciências do Desporto. Porto, v.7, n.3, 2007.

DUMAZEDIER, J. Valores e conteúdos culturais do lazer. São Paulo: Sesc, 1980.

FIGUEIREDO, J. Atividades de aventura e formação profissional: aspectos acadêmicos e de mercado de trabalho. In: PEREIRA, E. et al. Esporte e turismo: parceiros da sustentabilidade nas atividades de aventura. Pelotas: Editora da UFPel, 2011.

GEERTZ, C. O saber local: novos ensaios em antropologia interpretativa. Petrópolis: Vozes, 2012 [1983].

GOMES, C. G. Lazer, trabalho e educação: relações históricas, questões contemporâneas. $2^{\mathrm{a}}$ ed. Belo Horizonte: Editora da UFMG, 2008.

ISAYAMA, H. F. Atuação profissional no campo do lazer. In: ISAYAMA, H. F, SÁ, E. P. Lazer, empresa e atuação profissional. Brasília: Sesi, 2006.

MARCELlinO, N. C. Lazer e Recreação: repertório por fases da vida. Campinas: Papirus, 2006.

MARCELLINO, N. C. Lazer e educação. 17. ed. Campinas: Papirus, 2013. 
MARCELlinO, N. C.; SAMPAIO, T. M. V. SAMPAIO.; CAPI, A. H.C.; SILVA, D. A. M. Políticas públicas de lazer - formação e desenvolvimento de pessoal: os casos de Campinas e Piracicaba. Curitiba: Opus, 2007.

MARINHO, A. Atividades na natureza, lazer e educação ambiental: refletindo sobre algumas possibilidades. In: Motrivivência. v.16, n. 22, jun. 2004, p. 47-69.

MINAYO, M. C. S.; DESLANDES; S. F.; GOMES, R. Pesquisa social: teoria, método e criatividade. Petrópolis: Vozes, 2009.

MOUNET, J.P. e CHIFFLET, P. Whitewater sports: from extreme to standardization. In: To the extreme: alternative sports inside and out. Rinehart \& Sidnor (Org.), State University of New York Press, 2003, p. 267-277.

PAIXÃO, J.; COSTA, V.; GABRIEL, R. O instrutor de esporte de aventura no Brasil: implicações ligadas ao processo ensino aprendizagem. Lecturas Educación Física y Deportes, v. 134, 2009.

PAIXÃO, J., et al. Risco e Aventura no esporte na percepção do instrutor. Psicologia \& Sociedade; 23 (2), p. 415-425, 2011.

PIMENTEL, G. Risco, corpo e socialidade no vôo livre. Tese (Doutorado em Educação Física). Faculdade de Educação Física, Universidade Estadual de Campinas, Campinas, 2006.

RIBEIRO, O. C. F. O profissional do lazer nos cruzeiros marítimos: entrei de gaiato no navio? In: CARVALHO, J. E. (Org.) Lazer no espaço urbano: transversalidade e novas tecnologias. Curitiba: Champagnat, 2006.

RIBEIRO, O. C. F. Um estudo das políticas públicas de lazer de Brotas/SP. Tese (Doutorado em Educação Física). Faculdade de Educação Física, Universidade Estadual de Campinas, Campinas, 2012.

RODRIGUES, C. As práticas de Lazer diante do acontecimento ambiental: processos de ambientalização e a compreensão do lazer enquanto prática social. Licere, Belo Horizonte, v.15, n.1, mar/2012, p.1-22.

SCHWARTZ, G. Emoção e aventura: expressões intervenientes no estilo contemporâneo do Lazer. Tese (Livre Docência), Universidade Estadual Paulista, Rio Claro, 2004.

SCHWARTZ, G. (Org.) A aventura no âmbito do lazer: as AFANs em foco. In: Aventuras na natureza: consolidando significados. Jundiaí: Fontoura, 2006, p. 23-33.

SCHWARTZ, G. e CARNICELLI FILHO, S. (Desin) Formação profissional e atividades de aventura: focalizando os guias de "rafting". Rev. Bras. Educ. Fís. Esp., São Paulo, v. 20, n. 2, p. 103-09, abr./jun. 2006.

SOUZA, F. O imaginário no rafting: uma busca pelos sentidos da aventura, do risco e da vertigem. São Paulo: Zouk, 2004.

STOPPA, E. Acampamentos de férias. Campinas: Papirus, 1999. 
STOPPA, E. et al. A Produção do conhecimento na área do lazer sobre as temáticas formação e atuação profissional nos anais do Enarel de 1997 à 2006. Revista Licere, Belo Horizonte, v.13, n.2, jun/2010.

STRATHERN, M. O gênero da dádiva. Campinas: Editora da Unicamp, 2006.

UVINHA. R. Juventude, lazer e esportes radicais. São Paulo: Manole, 2001.

UVINHA. R. Esportes radicais e turismo: análise conceitual. In: TRIGO, L. (Org.) Análises regionais e globais do turismo brasileiro. São Paulo: Roca, 2005, p. 437447.

WACQUANT, L. Corpo e alma: notas etnográficas de um aprendiz de boxe. Rio de Janeiro: Relume Dumará, 2002.

WERNECK, C.L.G.; STOPPA, E. A.; ISAYAMA, H.F. Lazer e Mercado. Campinas: Papirus, 2001 (Coleção Fazer/Lazer).

WHEATON, B. (Ed.) Understanding lifestyle sports: consumption, identity and difference. London and New York: Routledge, 2004.

\section{Endereço das Autoras:}

Marília Martins Bandeira

Faculdade de Educação Física

Universidade Estadual de Campinas

Av. Érico Veríssimo, 701

Campinas - SP - 13083-851

Endereço Eletrônico: mariliamartinsbandeira@gmail.com

Olívia Cristina Ferreira Ribeiro

Faculdade de Educação Física

Universidade Estadual de Campinas

Av. Érico Veríssimo, 701

Campinas - SP - 13083-851

Endereço Eletrônico: oliribeiro@uol.com.br 